\title{
學 術論文-...
}

\section{熔接組立枌り挫屈に關する研究 (第 1 報)*}

一熔接鈑桁 の据 万挫屈一

奥 村 能 惠**

\section{A Study on the Buckling of Welded Built-up Structure (Report 'I)*}

-The lateral (torsional) buckling of welded plate girder-

By T. Okumura**

\begin{abstract}
In the present report, the author attempted to give a practically applicable method for the most economical design of the welded built up I-girder which is subjected to a bending moment. In the first place, he developed a theory on the lateral buckling, in which the deformation of web plate was considered, and the local buckling of flange plate.

The results of his study were as follows:

1) The formula which gives the critical value of the lateral buckling of I-girder had two more terms added to the already known one. These important corrected terms set a certain limit especially to the depth and width of flange plate. This formula was shown as (24) in this paper.

2) The local buckling strength of flange plate, in which the elastic supported condition by web plate was considered, decreased with the increase of $h / b$ and $d / t$ where

$h$ : height of web plate, $t$ : depth of web plate

$b$ : 'width of flange plate and $d$ : depth of flange plate.
\end{abstract}

\section{はしがき}

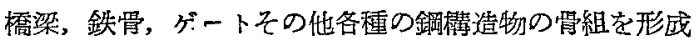
する部材に板材を互に隅肉熔接した組站材を使用すること は，鋲接㔍造に比し余計な材粼が不要で使用材料の節約を 期待することができる、特に自重に依る応力の暂しいるの にとっては有利な条件を示すのの゙ある。な知任意の形状

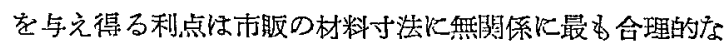

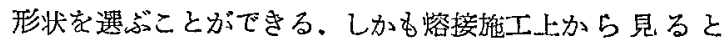
き，先ずJ.I.S K合格した SS41 の材料であれば，いわゆ る熔接歪の問題以外には現在の技術水淘で十分にこなし得

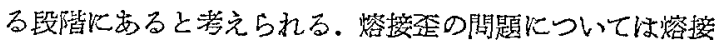
順序, 治具等の適当な使用火依って解决されつ小方り,こ れКついては別の研觉飞まっことにする．徉ってこれ等の 組红材に依りできがった部材を結合して，一つの目的に 適った構造物につくらまげる最后の接合に銛接を利用する

* [原稿受付 昭和 27 年 9 月

** 正貫 東京大学工学部 Member, Faculty of Engineering. Tokyo University.
が，熔接を利用するが，その搆造物の性格委たは支配す

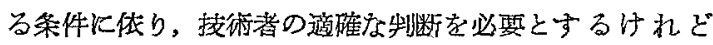
屯, 各部の部材に設計上最子合理的と考えられる部材を熔 接に依って集成して便用することは大、以舅まれる次第で ある。唯この第合留意しなければならない重要な点は，徒 来の鋲接搆造に怙いて添接された一見余計に思法れる部材

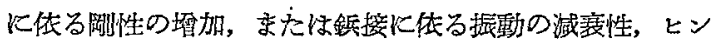

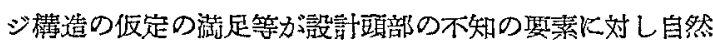
の圤抗をなしてきた点を無視してはならない点である。す なわら熔接組立材心構造上の特留を十分に理解し，生じ得 るすべての場合を考慮して各部の設計の基蕉をつくりおげ ることが大眐であると考えられる。

この第一の段階として，逆常最も多く使用されているI 断面の熔接桁の場合について教えてみよ弓．な嗬重条件 としては闍題をわかり易くするために單純曲げモーメント Mを受けた場合に制限して見る。その他の荷更条件の場合 む幾分の取报い上の復維さは岕るにしてる，I断面の桁が 曲げモーメントの形で積載荷直を分担し，伀逵する本来の 性賀を考えて見ると意味する所は同じであり，一つの修正 
された代表値と見なしてよいと考えられる。

さてI断面の洐は通常ウエブとよばれる1枚の板とフラ ンジとよ゙れる2枚の板より形成されており,フランジは 主として曲げモーメントK传る縁応力に抵捖し，ウェブは 剪断力をつたえる材であることはこ小に説明する迄すない ことである.

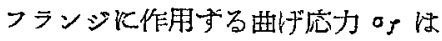

$$
{ }^{\circ}=M / W
$$

但し $\boldsymbol{W}:$ 断面保数

である. I断面の場合仁注

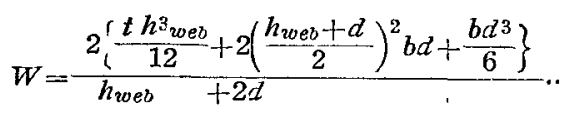

但し $\boldsymbol{t}, \boldsymbol{d}$ はそれぞれウエブ，フランシの板厚

$h_{w e b, ~} b$ は夫夫ウエプの高さ及びフランジの幅を

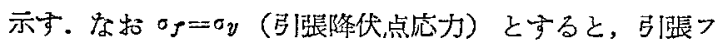
ランジが降伏する限界の曲げモーメント $M_{t}$ 柱

$$
M_{t}=W \cdot \sigma_{y}
$$

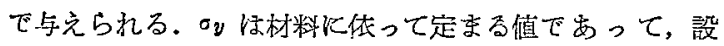
計条件を支配すを值は $W$ である。般にWの值は近似的 にフランジの断面積とジンブの高さと比例すると考えるこ とができをから，同じフランジの断面䅪であウエブの高さ を大きくすればする伍ぞ（3）式の及について考穴れば担 抗曲げモーメントが大となり，経佩的な設計が可能となる 訳である。しかしウェブの高さが大となると，ウエブ自身 の挫屈强度が低下し，当然その简さに制限が生ずる。

一方フランジの断面積は, 銽接構造の場合のようにアン グルを使用しない為，簡笚飞なり，その厚さと幅の $2 つ Q$ 值で代表することができる。フランジの厚さは使用材料の 蛒接性よりあ交り大きな值をとることができない。通常 1 枚の板としては $25 \mathrm{~mm}$ 位が窐京しい制限厚さである。

従ってフランジの面積を大きくするためにはその幅を大 きくすることになる。この幅をあまり大きくすると，突出 長が大となる結果，フランジ自身の局部的な挫展が支配策 件となり，医縮側フランジの挫屈に依って抵抗曲げモーメ ントの大きさが定まるこをになる。

建築学会の構造基蕉に依ると「アランジの突出量はその 厚さの15倍以下にする」こと孛規定している。この条件は 匟縮僋フランジの局部挫屈値より扎さえた值と思ほれる が.これについても挨討をかえてみることにする。

なおフランジとウエブを別別に考えたが，乙れはウェブ

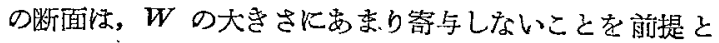
したものである.しかしフランジの厚さとシェブの厚さが あ委り不均衙になることは, フランジの櫝方向の用性とウ エプの横方向の剛性の不均衡の原因となり，桁が㨝りを受 けた場合，ウエブの支持㴊性の低いためフランジの負担す

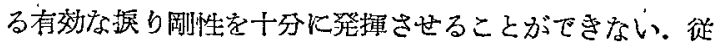

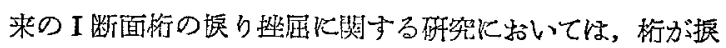
りを受けた場合もッエブは常に直線を保つ仮定に基いて計 算を行っている.徉ってこれより得られた結果はフランジ の㨝り剛性を大炕すればするほど，据り挫屈值が高くなる 結果を示していて；この研聟飞は十分な説明を与えること が出きない。このためにはッエブが変形する仮定の下に立 って据り挫屈の理論をたてる必要が岕る。とのようKする ことに依ってッェブとフランジの断面の均衡を定める条件 がラえられる訳である。

本論交は以上の見地に立って，ウエブの贸形を考葟した

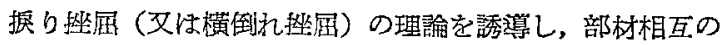
有効かつ均衡のとれた寸法の関係に関する検討を試み上了 としたものである。

ウエブの変形を若慮したI断面桁の㨝り挫屈

\section{§1. 基礎徽分方程式の誘道}

図 1 の左に示す基本的な形をした I 断面䘕が，右に示す 形の店り变形定生じた場合について考えてみよう。この場

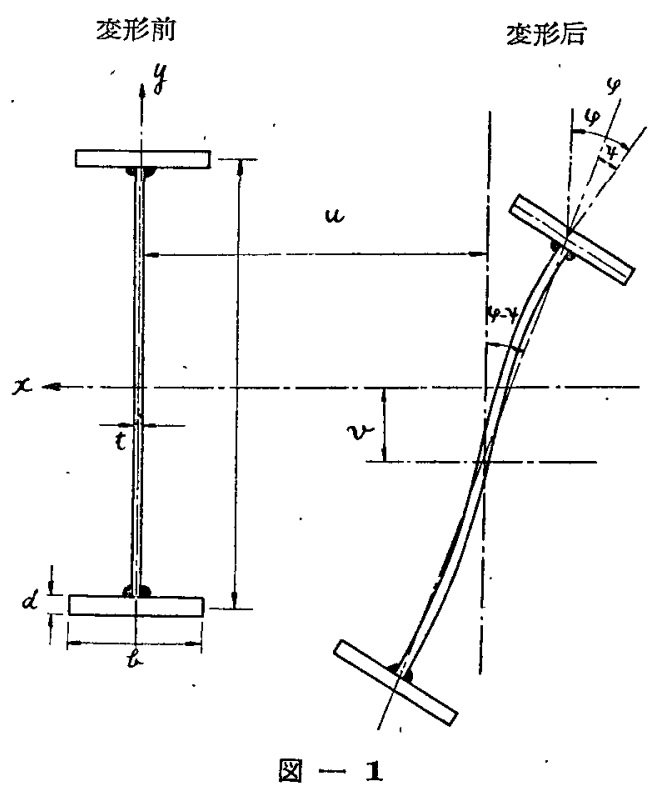

合変形后むフランジとウェブはそのつけ根において互に直 角を保っと考光, 桁重心の $x, y$ 方向の変位を $u, v>$ ラ ンジの回転角を. 結ぶ線とフシンジの法線となす角をせとする。なおウエブ は曲げを受持つ性賀（曲げ風性 $B_{\text {web }}=E I_{\text {web }}$ ）と据りを

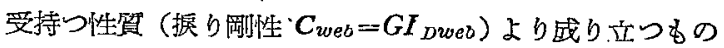
と仮定する。すなるち板構造としての曲げ变形を考えると 非常に問題が複雜となるが，この厳密な取报いは今后の取 扱いK対し，次数の高い微小項を附加するものだあるが，

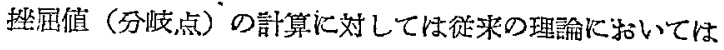
一店無視することがてきる、徉って枌の長さの方向妾 $\boldsymbol{z}$ 朝 
とすると，曲げと担抗する單位幅の $y$ 方向の部片と据りに 抵抗する㿢位湢の $z$ 万间の部片よりウエブが形成されてい るものと仮定しても開題の解折に矛盾を与えないと考えら れる。

さて図 2 比示す $d z$ なる要素を考光ここ泎用する据 りモーメントを $d M$ とする。これに刘し，フランジ， ウ エブKそれぞれ抵捖搌りモーメント $M_{z_{F}}, M_{\varepsilon w e b}$ フラン ジ剪断力 $R_{z}$ が対店し， $d z$ をねなれた断面飞图の如き状 熊となって均合うことになる。

$$
\left.\begin{array}{c}
-1 / 2 h^{2} D\left(d^{3} \varphi / d z^{3}-d^{3} \Psi / d z^{3}\right)+C_{w e v}(d \varphi / d z \\
-d \Psi / d z)+C_{F l} d \varphi / d z=-M_{z} \\
\Psi==-h C_{F l} / 6 B_{w e v}\left(d^{2} \varphi / d z^{2}+1 / 2 C_{F l} d M_{z} / d z\right)
\end{array}\right\}
$$

図一 4 K示す如き网端に單純曲げモーメント $M$ が作用 し，横方向に据り挫屈を生じた場合について考えて見乃。

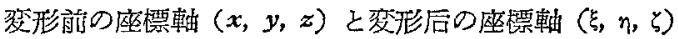
の問には，图一1上り表一1飞示す椂な方向余弦を持つこ とが云える。

從って弾性曲線のみ老*1考罢すると，

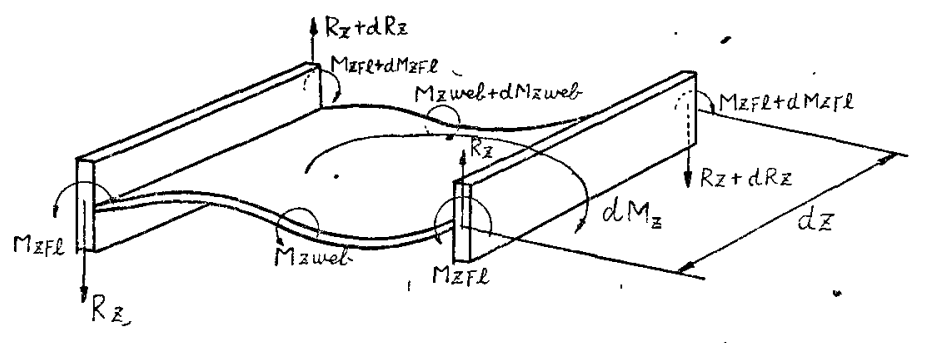

㘣 -2
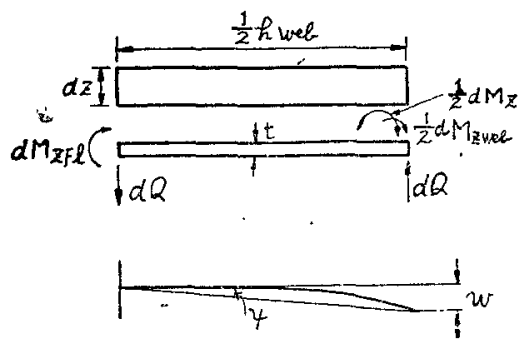

図-3

従って均合笨件としては

$d R_{z} \cdot h+2 d M_{z F l}+d M_{z w e b}=-d M_{z}$

または

$$
R_{z} \cdot h+2 M_{z F^{\prime}}+M_{z w e b}=-M_{z}
$$

となる。

但し $\left.\begin{array}{l}M_{z F l}=C_{F i} d \varphi / d z \\ M_{z w e b}=C_{w e b}(d \varphi / d z-d \Psi / d z\end{array}\right\}$

$h$ ほフランジの中心線間の距離， $C_{F l}, C_{w e \downarrow}$ はフラン ジ,ウェブの振り剛性を示す。

またフランジの剪断力の条件はフランジの橫方向の撓の 差から生ずるものであり，晋通の梁の撓に関する理論より

$$
R_{z}=-D \cdot \frac{1}{2} h\left(d^{3} \varphi / d z^{3}-d^{3} \Psi / d z^{3}\right.
$$

但し $D=E I_{F l}$ はフランジの $y$ 軸に関する曲げ岡性 を示す.

な招泩ずる条件任，フランジとウエブのつけ根と括

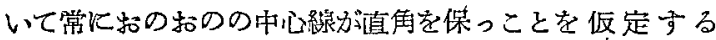
と，その仮定を满足するようにフランジ， ウェブの抵抗据 りモーメントがウエブの曲げに抵抗すると仮定した單位幅 の $y$ 方向の細片㳑一 3 K示す如き曲げモーメントを作用 する結果より生ずるものである。

これは簡單な梁の颎理論より計算されれ，

$$
\begin{aligned}
& \Psi=w / 1 / 2 h_{w e b} \doteqdot-h / 6 B_{w e v}\left(d M_{z F v} / d z\right. \\
& \left.+1 / 2 d M_{z} / d z\right)
\end{aligned}
$$

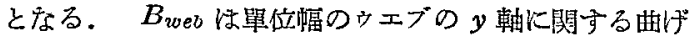
䣓性を示す。

（1）及び（4）式に（2）（3）式を代入すると
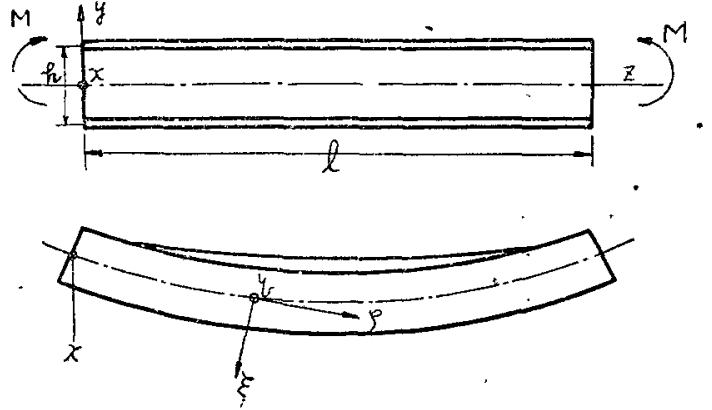

図 - 4

$$
B d^{2} u / d z^{2}=\left(\varphi-\Psi^{*}\right) M
$$

\begin{tabular}{|c|c|c|c|c|}
\hline & $x$ & $y$ & $z$ & の $y$ 軸に関李 \\
\hline & 1 & $-(\varphi-\Psi)$ & $-d u / d z$ & 示す。 \\
\hline & $-(\varphi-\Psi)$ & 1 & $-d v / d z$ & $M_{z}=d u$ \\
\hline & $d u / d z$ & $d v / d z$ & 1 & \\
\hline
\end{tabular}

$-1 / 2 h^{2} D\left(d^{3} \varphi / d z^{3}-d^{3} \Psi^{*} / d z^{3}\right)+C_{w e 3}(d \varphi / d z$ $-d \Psi / d z+2 C_{F} d \varphi / d z=-d u / d z M$

表 -1

$B$ 注桁全体

を考葸し，(5)，(6)，(7)式よりuを消去すると， $\varphi ， \Psi 火$ 関する式が話筧できる。

すなおち

$\left.\begin{array}{l}d^{2} \varphi / d z^{2}=-6 B_{w e b} / h C_{F l} \Psi-M^{2} 2 C_{F l} B(\varphi-\Psi) \\ 1 / 2 h^{2} D\left(d^{4} \varphi / d z^{4}-d^{4} \Psi / d z^{4}\right)-C_{w e b}\left(d^{2} \varphi / d z^{2}\right. \\ \left.-d^{2} \Psi, d z^{2}\right)-2 C_{F \imath} d^{2} \varphi / d z^{2}=M^{2} / B(\varphi-\Psi)\end{array}\right\}$

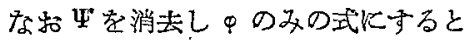

$$
d^{6} \varphi / d z^{6}+a d^{4} \varphi / d z^{4}+b d^{2} \varphi / d z^{2}+C \varphi=0
$$




$$
\left.\begin{array}{l}
a=-\left(6 B_{w e b} / h C_{F l}-2 C_{w e b} / h^{2} D\right) \\
b=-12 B_{w e b} / h^{3} D C_{F^{2}}\left(2 C_{F i}+C_{w e \downarrow}\right) \\
c=-12 B_{w e b} M^{2} / h^{3} D C_{F l} B
\end{array}\right\}
$$

となる。

一方

$$
\left.\begin{array}{l}
\Psi^{n}=1 / g^{2}\left(f^{2} \varphi+d^{2} \varphi / d z^{2}\right) \ldots \ldots \ldots \ldots \ldots \\
g^{2}=-6 B_{w e b} / h C_{F l}+M^{2} / 2 C_{F l} B_{1} \\
f^{2}=M^{2} / 2 C_{F l} B_{1}
\end{array}\right\}
$$

となる。

\section{§2．，両端單純支持の場合の挫屈値の誘導}

(9) 式K $\varphi=e^{\lambda z}$

を代入し， $\lambda^{2}=\mu$ と特くと

$\mu^{3}+a \mu^{2}+b \mu+c=0$

この三次式の 3 つの根品 $\mu_{2} \mu_{3}$ は

$$
\begin{aligned}
& p=b-a^{2} / 3 \\
& q=2 / 27 a^{3}-1 / 3 a b+c \\
& l==\sqrt[3]{-\frac{q}{2}+\sqrt{(q / 2)^{2}+(p / 3)^{3}}} \\
& m=\sqrt[3]{-\frac{q}{2}-\sqrt{(q / 2)^{2}+(p / 3)^{3}}} \\
& w_{1}=\frac{-1+\sqrt{-3}}{2} \\
& w_{2}=\frac{-1-\sqrt{-3}}{2}
\end{aligned}
$$

と怙くと，夫々 $(l+m-a / 3)\left(w_{1} l+w_{2} m-a / 3\right)$

$\left(w_{2} l+w_{1} m-a / 3\right)$ で与えられる.

従って

$$
\left.\begin{array}{l}
\lambda_{2}^{1}= \pm \sqrt{(l+m-a / 3)}= \pm \beta_{1} \\
\lambda_{4}^{3}= \pm \sqrt{\left(w_{1} l+w_{2} m-a / 3\right)}= \pm \beta_{2} \\
\lambda_{6}^{5}= \pm \sqrt{\left(w_{2} l+w_{1} m-a / 3\right)}= \pm \beta_{3}
\end{array}\right\}
$$

と就くと，(13）より（9）式老茫足するゅの値が与えられ る.

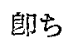

$\Psi=c_{1} \cosh \beta_{1} z+c_{2} \cosh \beta_{2} z+c_{3} \cosh \beta_{3} z+c_{c} \sin \beta_{1} z$ $+c_{5} \sinh \beta_{2} z+c_{6} \sinh \beta_{3} z$

(11) 式よb

$$
\begin{aligned}
& \Psi=-\frac{1}{g^{2}}\left\{c_{1}\left(\beta_{1}^{2}+f^{2}\right) \cosh \beta_{1} z+c_{2}\left(\beta_{2}^{2}+f^{2}\right) \cosh \beta_{2} z\right. \\
& +c_{3}\left(\beta_{3}{ }^{2}+f^{2}\right) \cosh \beta_{3} z+c_{4}\left(\beta_{1}^{2}+f^{2}\right) \sinh \beta_{1} z \\
& \left.+c_{5}\left(\beta_{2}{ }^{2}+f^{2}\right) \sinh \dot{\beta}_{2} z+c_{6}\left(\beta_{3} 2+f^{2}\right) \sinh \beta_{3} z\right\} \quad \text { (18) }
\end{aligned}
$$

\section{境界条件}

端部で自由な据り角を生じない羕にし，かつフランジに 対してはy軸に関する曲げを生じないよ5な自由な支持を なしているすのと考学ると，

$z=0$ Kおいて

$$
\begin{aligned}
& \varphi=\Psi=0 \ldots \ldots \ldots \ldots \ldots \ldots \ldots \ldots \ldots \\
& \frac{d^{2} y}{d z^{2}}=\frac{h}{2}\left(\frac{d^{2} \varphi}{d z^{2}}-\frac{d^{2} \Psi}{d z^{2}}\right)=0
\end{aligned}
$$

枌中央に関し対称なる条件より，中块部のフランジには 剪断力が生じ得ない。かつウエブが算続であり，据りモー メントむ0となるから

$$
\begin{aligned}
& z=\frac{l}{2} \text { に技いて } \\
& d y / d z=h / 2(d \varphi / d z-d \Psi / d z)=0
\end{aligned}
$$

$-1 / 2 h^{2} D\left(d^{3} \varphi / d^{3}-d^{3} \Psi / d z^{3}\right)=0$

となる。

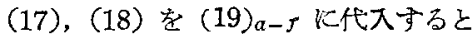

$$
c_{1}+c_{2}+c_{3}=0 \text {. }
$$$$
\left(\beta_{1}^{2}+f^{2}\right) c_{1}+\left(\beta_{2}^{2}+f^{2}\right) c_{2}+\left(\beta_{3}^{2}+f^{2}\right) c_{3}=0
$$$$
\left\{\beta_{1}^{2}+\beta_{1}^{2}\left(\beta_{1}^{2}+f^{2}\right) / g^{2}\right\} c_{1}+\left\{\beta_{2}^{2}+\beta_{2}^{2}\left(\beta_{2}^{2}\right.\right.
$$$$
\left.\left.+f^{2}\right) / g^{2}\right\} c_{2}+\left\{\beta_{3}{ }^{2}+\beta_{3}{ }^{2}\left(\beta_{3}^{2}+f^{2}\right) / g^{2}\right\} c_{3}=0
$$$$
\beta_{1} \sinh \beta_{1} l / 2 c_{1}+\beta_{2} \sinh \beta_{2} l / 2 c_{2}+\beta_{3} \sinh \beta_{3} l / 2 c_{3}
$$$$
+\beta_{1} \cosh \beta_{1} l / 2 c_{4}+\beta_{2} \cosh \beta_{2} l / 2 c_{5}
$$$$
+\beta_{3} \cosh \beta_{3} i / 2 c_{6}=0
$$$$
\left.\beta_{1}\left(\beta_{1}^{2}+f^{2}\right) \sinh \beta_{1} l / 2 c_{2}+\beta_{2}^{2}+f^{2}\right) \sinh \beta_{2} l / 2 c_{2}
$$

$+\beta_{3}\left(\beta_{3}{ }^{2}+f^{2}\right) \sinh \beta_{3} l / 2 c_{3}+\beta_{1}\left(\beta_{1} 2\right.$

$\left.+f^{2}\right) \cosh \beta_{1} l / 2 c_{4}+\beta_{2}\left(\beta_{2}{ }^{2}+f^{2}\right) \cosh \beta_{2} l / 2 c_{5}$

$+\dot{\beta}_{3}\left(\beta_{3}{ }^{2}+f^{2}\right) \cosh \beta_{3} l / 2 c_{6}=0$

$\left\{\beta_{1}{ }^{3}+\beta_{1}{ }^{3}\left(\beta_{1}{ }^{2}+f^{2}\right) / g^{2}\right\} \sinh \beta_{1} l / 2 c_{1}+\left\{\beta_{2}{ }^{3}\right.$

$\left.+\beta_{2}{ }^{3}\left(\beta_{2}{ }^{2}+f^{2}\right)\right\} \sinh \beta_{2} l / 2 c_{2}+\left\{\beta_{3}{ }^{3}+\beta_{3}{ }^{3}\left(\beta_{3}{ }^{2}\right.\right.$

$\left.\left.+f^{2}\right) / g^{2}\right\} \sinh \beta_{3} l / 2 c_{3}+\left\{\beta_{1} 3+\beta_{1}{ }^{3}\left(\beta_{1}{ }^{2}\right.\right.$

$\left.\left.+f^{2}\right) / g^{2}\right\} \cosh \beta_{1} l / 2 c_{4}+\left\{\beta_{2}{ }^{3}+\beta_{2} 3\left(\beta_{2} 2\right.\right.$

$\left.\left.+f^{2}\right) / g^{2}\right\} \cosh \beta_{2} l / 2 c_{5}+\left\{\beta_{3}{ }^{3}+\beta_{3}{ }^{3}\left(\beta_{3}{ }^{2}\right.\right.$

$\left.\left.+f^{2}\right) / g^{2}\right\} \cosh \beta_{3} l / 2 c_{6}=0$

$c_{i}(i=1 \cdots \cdots \cdot 6)$ が同特に0となる以外の根を有するため には，各係数よりつくられた行列式加0となるを慗する。 この值は整理して諳算すると

$$
\frac{\beta_{1} \cdot \beta_{2} \cdot \beta_{3}}{g^{4}} \cosh \frac{\beta_{1} i}{2} \cosh \frac{\beta_{2} l}{2} \cosh \frac{\beta_{3} l}{2}\left(\beta_{2}{ }^{2}-\beta_{1}\right)^{2}
$$$$
\left(\beta_{3}^{2}-\beta_{2}^{2}\right)^{2}\left(\beta_{1}^{2}-\beta_{3}^{2}\right)^{2}=0
$$

(14)式㳉か飞等根及び0なる根を有しないから

$\beta_{1} \neq \beta_{2} \neq \beta_{3} \neq 0$ となり，

(21)式の 条件忹

$$
\cosh \beta_{i} / / 2=0 \quad(i=1,2,3)
$$

となる. 徒って $i \beta_{i} l / 2=n \pi / 2$ ，自溗して，

$-\beta_{i}{ }^{2} l^{2}=n^{2} \pi^{2}$ となれば行例式=0の条件式を満足する。

これは（14）式の根の性筫より，

$$
\left(\frac{a}{3}-\frac{n^{2} \pi^{2}}{l^{2}}\right)^{3}+p\left(\frac{a}{3}-\frac{n^{2} \pi^{2}}{l^{2}}\right)+q=0
$$

となればよい，(23)，(10)，(15）を用いると行列式 $=0$

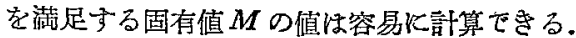

すなわち 


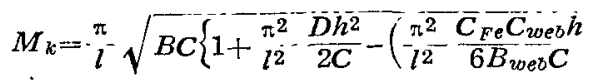

$$
\begin{aligned}
& \left.\left.+\frac{\pi^{4}}{l^{4}} \frac{C_{F e} D h^{3}}{12 B_{w e b} C}\right)\right\} \\
& \mathrm{C}=2 C_{F} \imath+C_{w e b}
\end{aligned}
$$

この㐿の根号の中の最初の 2 項任往来の理論より求めら れた值であり，後の括㧓の中にある2 項がこの理論より出 された補正項で岕る。

\section{数值計算例}

フランジの輻及び厚さを $b, d$, ウェブの高さ及び厚さを $t$ とすると

$$
\begin{aligned}
& B_{w e b}=-\frac{t^{3}}{12} E \\
& D=-\frac{d b^{3}}{12} E \\
& B \quad=\left(-\frac{h t^{3}}{12}+2 \frac{d b^{3}}{12}\right) E \\
& C_{F l}=\frac{b d^{3}}{3}(1-0.630 d / b) G \\
& C_{w e b}=h t^{3} / 3(1-0.630 t / h) G
\end{aligned}
$$

で与えられる.

令 $h=160 t^{* 3}, a=m t, b=n d, l=\gamma h$ と括くと，圂一5,

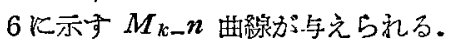

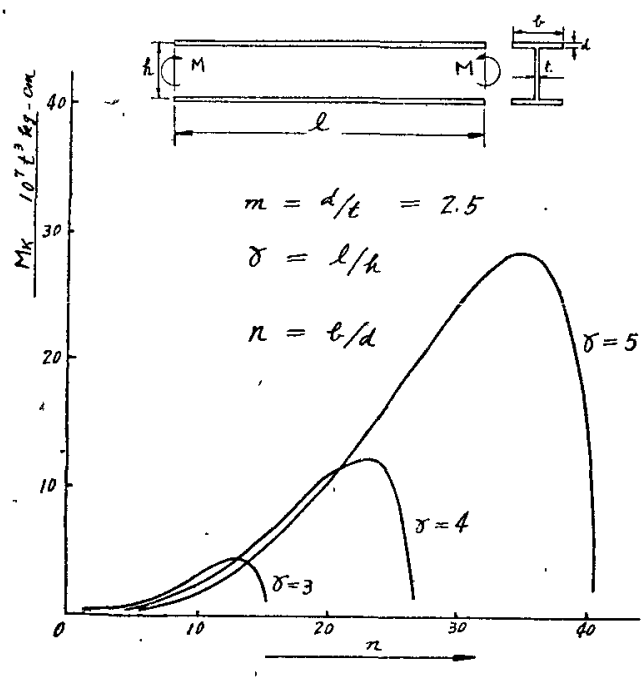

図 -5

註 $t$ 単位: $\mathrm{cm}$

図一 5 は $m=2.5$ とし， $\gamma$ の变化に依る性筫をしらべた ものであり，図一 6 ほ $\gamma=5$ とし， $m$ の恋化に依る性筫を しらべたものである。

図惊フランジ幅を或程度以上の大きさにすると据り拱抗

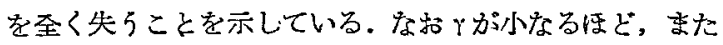
m分大なる萎ど低いnの限界值を示すことが示されてい る.これはフランシの不均衡の撕り佣性が無效となる限界 を示すをの்と考えられる。

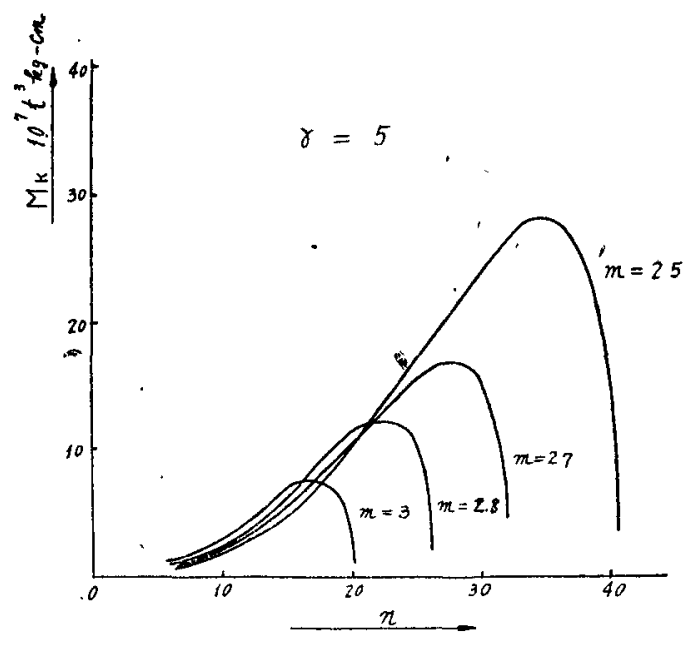

図 - 6 記号図一 5 参照

\section{§3. ウエブ及びフランジの局部挫屈}

ウエブ及びフランジの局部挫屈は夫るが板材として荷雷 を受けたときの幽屈状態に依つて定められる。

一般に板材の挫屈は荷重索受ける辺の長さを $b$, 板厚を $t$ ，ポアソン比をンとするとき

$$
\sigma_{k}=k \frac{E \pi^{2}}{12\left(1-v^{2}\right)}\left(\frac{t}{b}\right)^{2}
$$

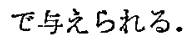

この式に示される $k$ の值は荷雷の性算及び周辺の支持の 条件に依って定められる值である。通労板の挫屈变形を支 配する基磷微分方程式を茫足する撓形を境界の支持状態を” 表わす境界条件式に代入してつくられた特性方程式より求 められる。また便宣的な方法として全变形ェネルギーの 变分式より求められる。

單純曲げモーメントを受けたI桁で, フランジ及びッエ ブが局部的な热屈变形の生ずる場合を想定すると,フラン ジでは压縮側フランジの縁沈力分フランジの板材としての

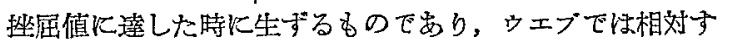
‘二辺に三角形分布の荷重を受け，その最大の度力が挫屈 値に達した時に生ずる。

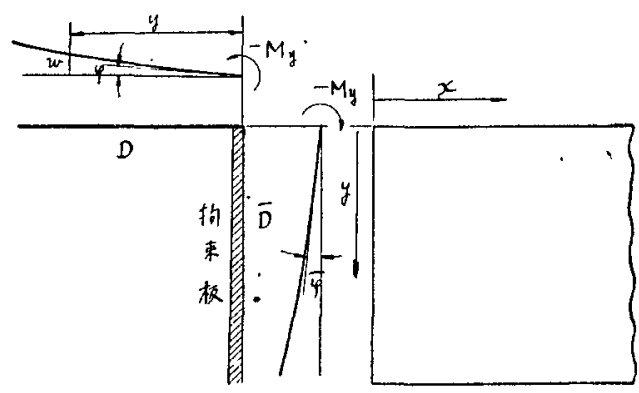

図一 7 
またこの場合の境界条件としてはウエブ，フランジ共に 荷再を受ける辺は單純交持であり，他の二辺はフランジに 刘しては半分の突出部分のみ考考衣，一辺自由支持，他辺 ウェブに依って弾性支持として取扱えばよい，またウェブ に対しては二辺フランジ依って弾性交持として取扱えば よい.

この場合の弾性支持条件は図一7K示壮状熊を考える と,

$$
M^{\prime} y=-\zeta \cdot \bar{\varphi}
$$

板の撓 $w$ で畫きか觉ると

$$
\left[\frac{\partial w}{\partial y} \pm \frac{D}{\zeta} \frac{\partial^{2} w}{\partial y^{2}}\right]_{y=\mp \frac{h}{2}}=0
$$

\section{で与えられる。}

な特との值㤝拘束板の周辺より $M_{y}$ なる曲げモーメン 卜を受ける場合の甲と $M_{y}$ の関係より求むればよい.

今拘束板の撓を $\bar{w}$ とし，図示の記昼を用い， $M_{y}=C \sin$ $m \pi x / l$ と仮定し， $w$ 軸に直角な二边分潬純支持の条件を 考圈すると

$$
\begin{aligned}
\bar{w}= & \left(\bar{c}_{1} \sinh -\frac{\pi y}{\lambda}+\bar{c}_{2} \cosh \frac{\pi y}{\lambda}+\bar{c}_{3} y \sinh -\frac{\pi y}{\lambda}\right. \\
& \left.+\bar{c}_{1}^{\prime} y \cosh \frac{\pi y}{\lambda}\right) \sin -\frac{m \pi}{l} x
\end{aligned}
$$

（但しスは接の $y$ 朝方向の半波長）で与えられる。

$\overline{c_{i}}(i=1 \cdots \cdots 4)$ を定める条件として添二枚の板の結合線 が同一直綮在保つと考光ると，その結合辺において

$$
\begin{aligned}
& \bar{w}=0 \\
& M_{y}=-\bar{D}\left(\partial^{2} \bar{w} / \partial y^{2}+v \partial^{2} \vec{w} / \partial x^{2}\right)
\end{aligned}
$$

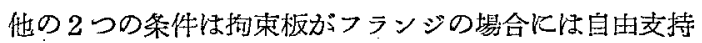

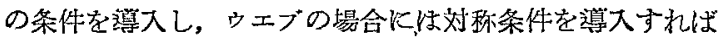
よい.

（26）と同じ条件式は拘束板に刘しても此立す゚。.この条 件を用いると

シエブが拘束板り場合

$$
\bar{\varphi}=-\frac{\lambda}{2 \bar{D}} \frac{1}{\pi} \tanh \frac{\pi h_{w e v}}{2 \lambda}\left[1+\frac{\pi h_{w e v} / \lambda}{\sinh \left(\pi h_{w e v} / \lambda\right)}\right] M_{\nu}
$$

フランジが拘束板の場合

$\bar{\varphi}=-\frac{\lambda}{2 \bar{D}}-\frac{1}{2 \pi} \frac{3 \cosh (\pi b / 2 \lambda)+\pi^{2} b^{2} / 4 \lambda^{2}+1}{\pi b / 2 \lambda+3 \sinh (\pi b / 2 \lambda) \cosh (\pi b / 2 \lambda)} M_{y}$

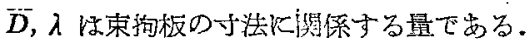

\section{フランジの局部挫座}

フランジの㔖出方向を $y$ 軸，桁方向を $x$ 軸にとると连 屈変形 $w$ を支配する微分方程式は

$D\left(\partial^{4} / \partial x^{4}+2 \partial^{4} / \partial x^{2} \partial y^{2}+\partial^{4} / \partial y^{4}\right) w+\sigma_{c} t \partial^{2} w / \partial x^{2}=0$

$$
\left.\begin{array}{l}
\mu^{2}=\sigma_{c} d / D(l / n \pi)^{2} \\
\theta_{1}=\frac{n \pi}{l} \sqrt{\mu+1} \\
\theta_{2}=\frac{n \pi}{l} \sqrt{\mu-1}
\end{array}\right\}
$$

と物くと

$w=\sin n \pi x / l\left(\overrightarrow{c_{1}} \cosh \theta_{1} y+\overrightarrow{\bar{c}_{2}} \sinh \theta_{1} y+\underset{c_{3}}{\vec{Z}} \cos \theta_{2} y\right.$

$\left.+\overline{\overline{c_{4}}} \sin \theta_{2} y\right)$

で与えられる。ここで前述の境界条件を尊入すると，特性 方程式が得られる。

すなおち

$$
\left.\begin{array}{l}
k_{1}=\theta_{2}{ }^{2}+v(n \pi / l)^{2} \\
k_{2}=\theta_{1}{ }^{2}-v(n \pi / l)^{2} \\
k_{3}=\zeta \frac{b}{4} \frac{\theta_{1}^{2}+\theta_{2}^{2}}{\theta_{1}}
\end{array}\right\}
$$

とおくと

$$
\begin{aligned}
& \frac{2 k_{1} k_{2}}{\cosh \theta_{1} b / 2 \cos \theta_{2} b / 2}+k_{1}{ }^{2}+k_{2}{ }^{2}-\frac{k_{1} 2 \theta_{1}{ }^{2}-k_{2} 2 \theta_{2} 2}{\theta_{1} \theta_{2}} \\
& \tanh \theta_{1} b / 2 \tan \theta_{2} b / 2+k_{3}\left(k_{2} 2 \tanh \theta_{1} b / 2-k_{1}{ }^{2}{ }_{\theta_{2}}^{\theta_{1}} \tan \right. \\
& \left.\theta_{2} b / 2\right)=0
\end{aligned}
$$

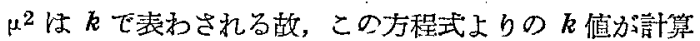
される。

これを図示すると図一 8 となる。

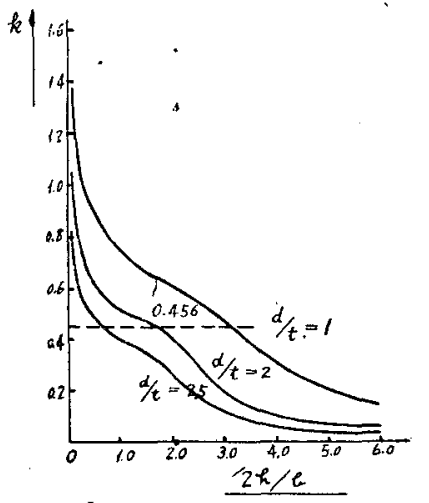

図一8 図-5 ○記号参照
この図で明かのよ5 K2h/bが大きい程, すなわちウェブ高さが 高い良ど局部挫底の屋 險性加增大する。しか しウエブ高さが高いこ とはフランジに生ずる 緣杧力を小炕すから この 2 つ互に相反す る事実が雷なることに 注意すべきである。な 搑従来フランジの局部

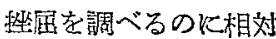
する荷重を受ける二辺單純交持，他の二辺は自由及び固定 交持として取扱っているが，これに拣ると $k$ の值*5惊 $2 l / b$ が十癹大のとき

$$
k=0.456+(b / 2 l)^{2}
$$

となることを示しているが，この值快明水閧フランジの 場合に荄当する.

\section{ウエプの局部性屈}

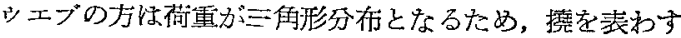
微分方程式力非線型となり，解析的に特性方程式を求める ことは团蜼である。徉来の取报に依ると*6 证辺單純支持の場合 


$$
l / h_{w e b}>\frac{2}{3} \quad k=23.9
$$

二辺（荷雷辺）單純支持. 他の二辺周定の埸合

$$
l / h_{w e b}>1.5 \quad k=39.7
$$

フランジの場合に見られる椱に固定とみなすことは亶す ぎる值を示するので安り，通常用いられる（33）の值を用 いてむ，フランジ幅のきわめて小さい場合をたはきわめて 大きい場合を除き墑用可能と考えられる。

ウエブの挫屈は剪断に依る挫屈が閪題で岕り，曲げに依 る挫届は比較的軽視されている.兴用的にもスチフナー等 に依る補强が比較的效果を発措している。

\section{\$4. まと め}

以上の取扱いを主として，I枌の寸法間の関保を考察し てみよ5.

最も單純なI标の場合でも，各寸法間の関係として $h / t$ ，

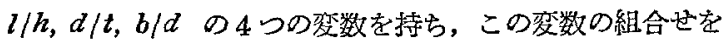
考えねばならぬ，実用的な圭場より考えると，フランジの 突时長と厚さの比すなわち $b / 2 d$ 㕛は $b / d$ を变数とし， 他の变数を固定した場合について調べることにする。

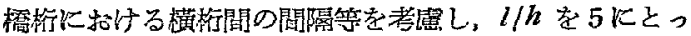
て見る．な特 $h$ に依る影響を調べるに際し，有效曲げモー メントは径間の大きさに比例することを洘慮し，l を一定

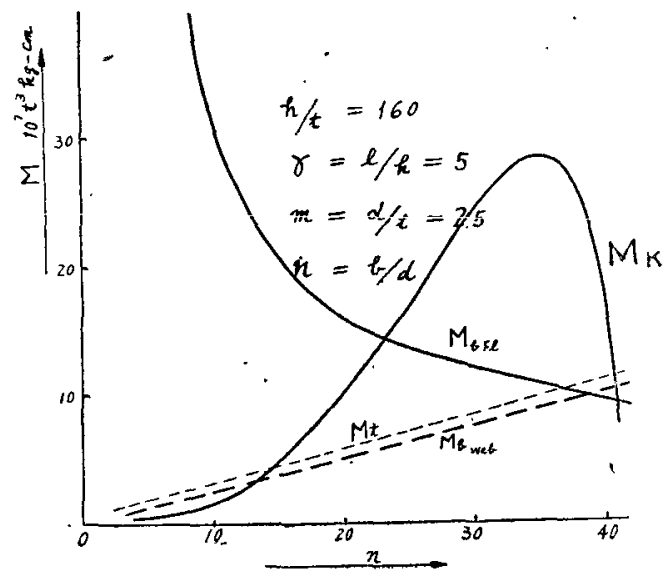

図 -9

註 $M_{k}$ 据り挫屈值……(24) 式に依万

$M_{t}$ フランシが引張降伏值に達する限界曲げ モーメント……(3) 式に依る $\sigma_{y}=2400 \mathrm{~kg} / \mathrm{cm}^{2}$ にこる。

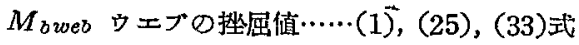
に依る。

(25)式 $t=t \quad b=h$ にてろ

$M_{b F^{\prime} l}$ 压縮侧フランジの局部挫屈の生する限 界曲げモーメント……(3), (25), (32) 式に依る

(25)式 $t=d \quad b=b / 2$ にさる

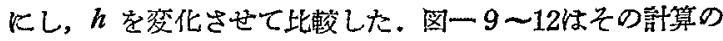
一例である、同じ桁高ですフランジとウェブの厚さの比 $a / l$ が大きすぎること恃，この計算の筑国内の枌高で 4

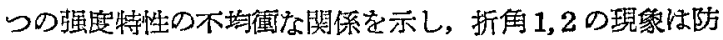
ぎ得ても仿の現象より不利となることになり十分に微断面 を利用したとはいえない，一方図一8よりす分る样炕槁 をこ敞上高くすると、フランシの厚さを溥くしない限り

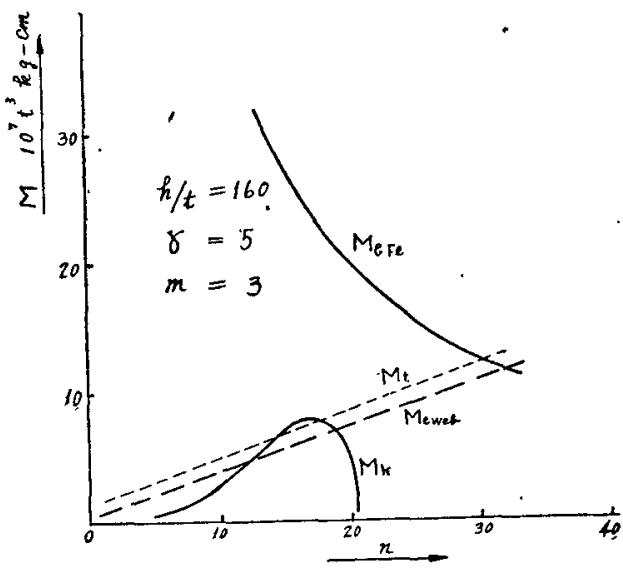

㘣 -10

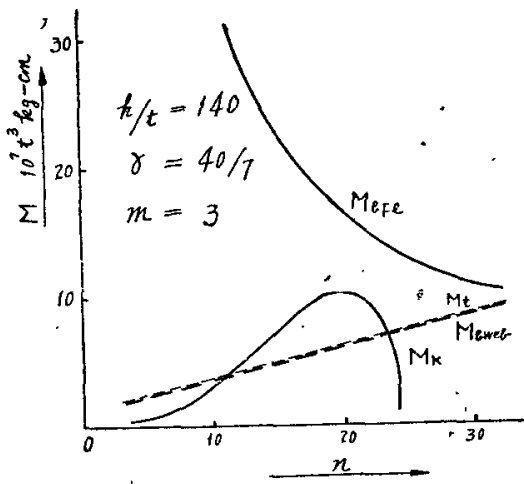

园 -11

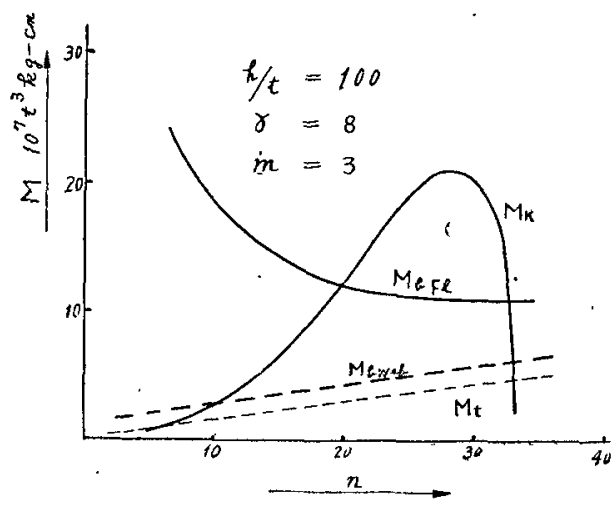

図 -12 
フランジの局部挫屈が支配的条件となり突出長の適当な選

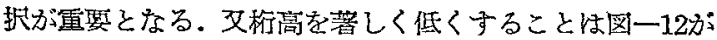

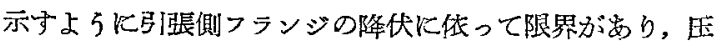
縮側フラシジは十分に利用し尽されない。

突出長の限界も $d / t, h / t$ 飞体って一義的飞与えること が出来ないが15〜20位が妥当な限界値と考它られる. 全体

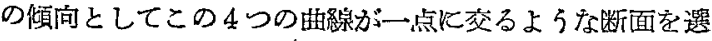
ぶことが好しいと考えられる。

最近欧米で盛え飞便用されているコンクリート床版と匟 縮側フランジを緊結させてその共同作用を利用している合

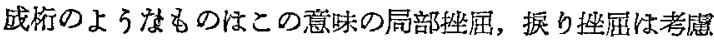
しないでるよい訳であって，熔接桁の持つ一つの缺点すな わち構造上の制限を除いている点, 有用な權造形式と言え るようである。

な特論ずべき問題が残っているが，実驗結果と共K新し く論じようと思う。

最后に本論文に関し御指導を受けた東大仲威婎㸚授に感
謝する次第である。

*ー1 䈌密には板として考えねばならないが，前に述 べた理由で従来と同じ取报いをした．䈗密にほ

$B^{a^{2} u} / d z^{2}+B y^{d^{2}}(\varphi-\Psi) / d z^{2}=(\varphi-\Psi)[M-M / w(1$ $-2 y / h) t\{u+y(\varphi-\Psi)\}]$ となる。

*-2 zのかわりとと書くべきであるが，便宣上 用いた。

*-3 現行の設計上最子経済的と考えられる桁高. 平 并敦著 鋼橋 参照

*ー4 压縮側フランジに等分布に縁店力が働くと考え て取报っているが，実際火は有勅幅の考方方から云って突 出長を大きくとりすぎると必ずしも等分布とは考えられな い.この点加らも突出長飞制限力泩ずる.

*-5 Timoshenko: Theory of elastic stability.

*-6 長柱研究委員会：弹性安定要覽

\section{資}

\section{米軍嫢格の解說} (I)

\section{MIL-T-5021 熔接工の技倆檢定}

中 村 孝*

朝群策唯勃発以来所謂「特需」なる形式に执いて，種々 の航空関係部品が発註せられ，敗戦後の空白に突如とし て，米国航空工業の一端を現わすに至った。戦後我が国熔 接の発達恬誠に見るべきるの多く，特炕造船界においては

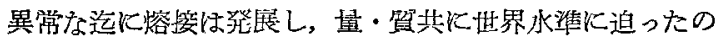
であるが，航空方面恃兵器工業として禁止品目に峁ったた

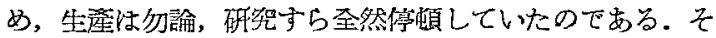
れがナパーム弹炕始まり，最近のジェッ下戦斗機用燃料タ ンクに至る各種航空関係部品に遭遇するや，忽ち種々の久 陷を露呈し，関係者注米国の技術水淮汇迫隨するのに非常 な努力を払ってきた。その内当面の問題性軍規格（Military Specification) である. 現在, 空軍成保の発註品は その検查をU.S. コンサルタシントというような成閏会社

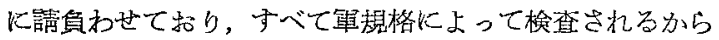

* 正員 㧣式会社: 電元社製往所
である、この規格性実汇完備されて扣り，相包材料から製 図，試潋等に至るまで龙大な範围に亘っている。我々揢接 関係者としてはこれ等の規格中，熔接関係のものについて

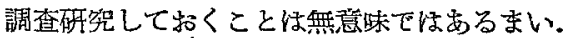

また米空軍閔係の特需はうけないまでる，我国直工業界 としては，好むと好まざるとに拘らず再軍備に件万航空工

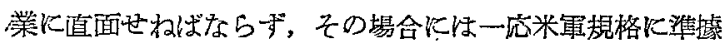
またはこれが参考にされることは当然想像されることであ り，他山の石として研究の価偩あるあのと考えられるので ある。一方米策規格にもどうかと思われる節もあり，一概 にう忝みにはできず，これらに是々非々を加えることも，

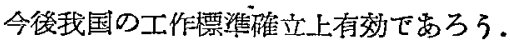

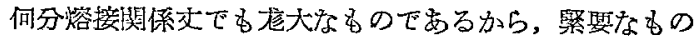
から逐次とり上げてみよう。

\section{米軍 規 格}

試驗：航空㙨熔接工技倆検定

$$
\text { MIL-T-5021 (1949-7-29) }
$$

\section{1. 䢩 用}

本規格は 1944-5-5 制定せられた AN-T-38a を旧規格 とするるので, AN (空海軍規格) が Federal Specification（国家規格）飞統一せられてずべて MIL 規格となっ たものの一つで， T は Test の Tである、本規格は酒素

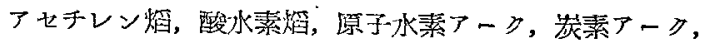
金䇩アーグよび不活性がスアーク譗接等を含む融接法に

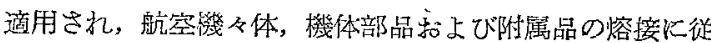

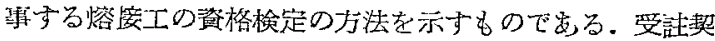
約が成立してるその契約の部品について熔接工の技脼検定 